\title{
Deposition nucleation on mineral dust particles: a case against classical nucleation theory with the assumption of a single contact angle
}

\author{
M. J. Wheeler and A. K. Bertram \\ Department of Chemistry, University of British Columbia, Vancouver, BC V6T 1Z1, Canada \\ Correspondence to: A. K. Bertram (bertram@chem.ubc.ca)
}

Received: 21 June 2011 - Published in Atmos. Chem. Phys. Discuss.: 27 July 2011

Revised: 2 January 2012 - Accepted: 3 January 2012 - Published: 30 January 2012

\begin{abstract}
Deposition nucleation on two mineral species, kaolinite and illite, was studied using a flow cell coupled to an optical microscope. The results show that the $S_{\text {ice }}$ conditions when ice first nucleated, defined as the onset $S_{\text {ice }}$ $\left(S_{\text {ice, onset }}\right)$, is a strong function of the surface area available for nucleation, varying from $100 \%$ to $125 \%$ at temperatures between 242 and $239 \mathrm{~K}$. The surface area dependent data could not be described accurately using classical nucleation theory and the assumption of a single contact angle (defined here as the single- $\alpha$ model). These results suggest that caution should be applied when using contact angles determined from $S_{\text {ice, onset }}$ data and the single- $\alpha$ model. In contrast to the single- $\alpha$ model, the active site model, the deterministic model, and a model with a distribution of contact angles fit the data within experimental uncertainties. Parameters from the fits to the data are presented.
\end{abstract}

\section{Introduction}

Atmospheric aerosol particles can indirectly influence climate by modifying the formation conditions and properties of ice and mixed-phase clouds. To better understand this topic, an improved understanding of the ice nucleation properties of atmospheric aerosols is required, and these properties need to be parametrized and incorporated in atmospheric models (Baker and Peter, 2008; Cantrell and Heymsfield, 2005; DeMott, 2002; Hegg and Baker, 2009; Houghton et al., 2001).

Ice nucleation may occur in the atmosphere either homogeneously or heterogeneously. Homogeneous nucleation in- volves the freezing of liquid droplets. In heterogeneous nucleation, ice forms on insoluble or partially soluble aerosol particles known as ice nuclei (IN). Four different modes of heterogeneous ice nucleation have been identified: immersion, condensation, deposition and contact nucleation. In the following we focus on deposition nucleation, which involves the formation of ice on a solid particle directly from the vapour phase (Pruppacher and Klett, 1997; Vali, 1985).

Different theories or models have been developed to parametrize heterogeneous nucleation data. One of the simplest is classical nucleation theory (Pruppacher and Klett, 1997) combined with the assumption of a single contact angle, $\alpha$. We refer to this as the single- $\alpha$ model. This model assumes ice nucleation is a stochastic process and can occur at any location on the surface of a particle with equal probability (i.e. the surface is energetically uniform for ice nucleation). Therefore, each particle has the same probability per unit surface area to nucleate ice (Pruppacher and Klett, 1997). Nucleation data is parametrized using a single parameter, the contact angle. Due in part to its simplicity, researchers (including ourselves) have used the single- $\alpha$ model to parametrize laboratory data for use in atmospheric simulations (see for example: Archuleta et al., 2005; Chen et al., 2008; Chernoff and Bertram, 2010; Eastwood et al., 2008, 2009; Fornea et al., 2009; Hung et al., 2003). In addition, the single- $\alpha$ model has been used to describe heterogeneous nucleation in atmospheric cloud simulations (see for example: Hoose et al., 2010a,b; Jensen and Toon, 1997; Jensen et al., 1998; Kärcher, 1996, 1998; Kärcher et al., 1998; Morrison et al., 2005). 
A modification of the single- $\alpha$ model is the Probability Distribution Function- $\alpha$ model (PDF- $\alpha$ model) (Lüönd et al., 2010; Marcolli et al., 2007). Similar to the single- $\alpha$ model, this model assumes that ice nucleation is stochastic and can be described by classical nucleation theory. Nucleation can occur at any location on the surface of a particle with equal probability (i.e. the surface is energetically uniform for ice nucleation). However, the ice nucleation ability varies from particle to particle, which is described by a probability distribution function of contact angles, $\alpha$. This model has recently been used to parametrize laboratory data of Marcolli et al. (2007) and Lüönd et al. (2010).

Yet another modification to the single- $\alpha$ model is the active site model (Fletcher, 1969; Gorbunov and Kakutkina, 1982; Han et al., 2002; Lüönd et al., 2010; Marcolli et al., 2007; Martin et al., 2001; Niedermeier et al., 2011). In this model it is assumed that ice nucleation is a stochastic process and can be described by classical nucleation theory. However, small areas or sites on a particle may be more effective at nucleating ice than the remainder of the particle. The distribution and ice nucleation properties of these areas, referred to as "active sites", govern the nucleating ability of a particle. The active site model has been used for parametrizing laboratory data and for describing ice nucleation in atmospheric models (Fletcher, 1969; Gorbunov and Kakutkina, 1982; Khvorostyanov and Curry, 2000, 2004, 2005, 2009; Kulkarni and Dobbie, 2010; Lüönd et al., 2010; Saunders et al., 2010).

A final model used here is the deterministic model (Connolly et al., 2009; Lüönd et al., 2010). Unlike the other three models discussed above, this model is not based on classical nucleation theory. When applied to deposition nucleation, the deterministic model assumes particles have a characteristic number density of surface sites, and ice forms immediately on a surface site upon reaching a definite ice saturation ratio. This model has been used recently to parametrize immersion nucleation data for mineral dust particles (Connolly et al., 2009; Lüönd et al., 2010; Murray et al., 2011; Niedermeier et al., 2010).

In the following we investigate deposition nucleation of ice on illite and kaolinite particles, two minerals that are a significant fraction (up to $50 \%$ ) of atmospheric mineral dust (Claquin et al., 1999). Mineral dust particles can play an important role in atmospheric ice formation based on previous field measurements and modelling studies (see for example: Ansmann et al., 2008; Barahona et al., 2010; Cziczo et al., 2004; DeMott et al., 2003; Heintzenberg et al., 1996; Hoose et al., 2008; Klein et al., 2010; Koehler et al., 2010; Li and Min, 2010; Min et al., 2009; Prenni et al., 2009; Sassen, 2002; Sassen et al., 2003; Seifert et al., 2010; Twohy and Poellot, 2005). We show that the $S_{\text {ice }}$ conditions when ice first nucleates on kaolinite and illite particles are a strong function of the surface area available for nucleation. This surface area dependent data is then used to test the different models discussed above. We show that the single- $\alpha$ model cannot describe the laboratory data, but the PDF- $\alpha$ model, the active site model and the deterministic model fit the data within experimental uncertainties. Parameters from the fits to the data are presented and the atmospheric implications are discussed.

\section{Experimental}

\subsection{Ice nucleation experiments}

The apparatus used in these studies has been described in detail previously (Dymarska et al., 2006; Eastwood et al., 2008; Parsons et al., 2004). It consists of an optical microscope (Zeiss Axiolab A equipped with a 10X objective) coupled to a flow cell in which the saturation ratio and temperature can be accurately controlled. The saturation ratio, $S_{\text {ice }}$, is defined as the ratio of water vapour partial pressure to the saturation vapour pressure of ice at the same temperature. Mineral dust particles were deposited on the bottom surface of the flow cell; the saturation ratio with respect to ice, $S_{\text {ice }}$, inside the cell was increased, and the conditions for onset of ice nucleation (when the first particle nucleated ice) was determined with a reflected light microscope. We define this as the onset $S_{\text {ice }}\left(S_{\text {ice, onset }}\right)$. The $S_{\text {ice }}$ over the particles was controlled by continuously flowing a mixture of dry and humidified $\mathrm{He}$ through the flow cell. The humidity of the gas stream was continuously monitored using a frost point hygrometer (General Eastern 1311 DR) which was calibrated against the ice frost point within the flow cell (Dymarska et al., 2006).

The bottom surface of the flow cell, which supported the particles, consisted of a glass cover slide treated with dichlorodimethylsilane to make a hydrophobic surface (Dymarska et al., 2006). This ensured that ice did not nucleate directly on the surface of the glass slide. The $S_{\text {ice }}$ conditions at which all the particles nucleated ice could not be determined since after ice formed on the first particle, the $S_{\text {ice }}$ above the other particles was reduced as water vapour condensed on the first nucleated particle. Each experiment involved determining the $S_{\text {ice, onset }}$ for an ensemble of particles and this procedure was repeated a number of times with varying numbers of particles. $S_{\text {ice, onset was determined for }}$ each sample once (i.e. measurements were not repeated on the same sample).

Typical experimental $S_{\text {ice }}$ trajectories used in these ice nucleation experiments are illustrated in Fig. 1. At the beginning of the experiments, the particles were exposed to a flow of dry $\mathrm{He}$ gas at room temperature $\left(S_{\text {ice }}<1 \%\right)$. The temperature of the cell was then rapidly lowered and the $S_{\text {ice }}$ was set to approximately $80 \%$. The nucleation experiments were then conducted by steadily decreasing the temperature $\left(-0.1 \mathrm{Kmin}^{-1}\right)$ and thus increasing the $S_{\text {ice }}$ as shown in Fig. 1 . The $S_{\text {ice }}$ ramp rate was approximately $1 \% \mathrm{~min}^{-1}$. Optical images were recorded every $20 \mathrm{~s}$, which corresponds to a change of $\sim 0.3 \% S_{\text {ice }}$. 


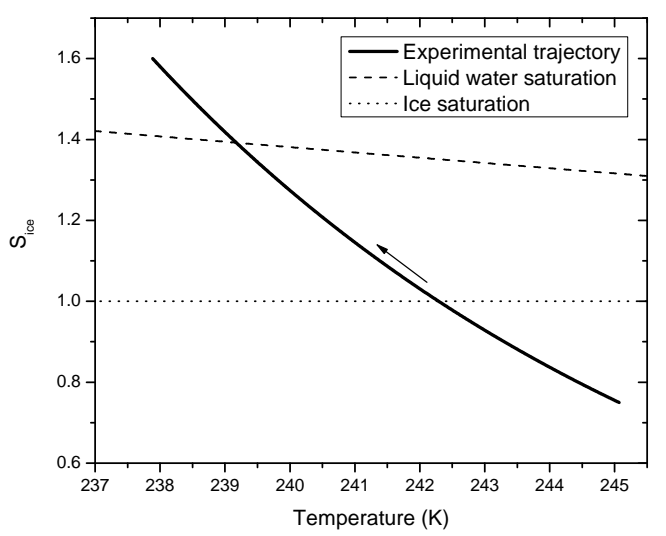

Fig. 1. Typical experimental trajectories for the ice nucleation experiments. Experiments start below ice saturation and the temperature is decreased until ice crystals are observed.
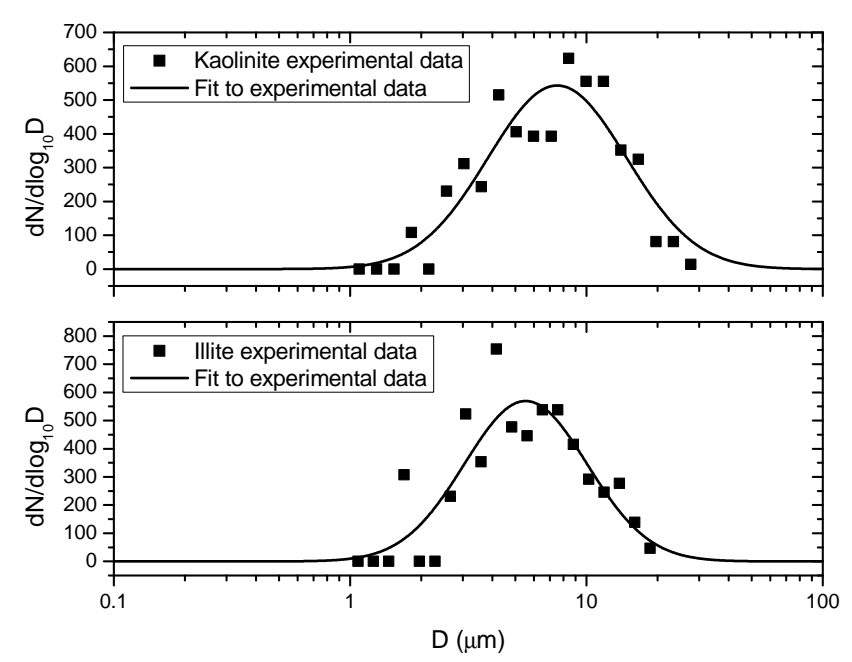

Fig. 2. Number distributions measured using the optical microscope. $N$ represents the cumulative number distribution function and $D$ represents the diameter. The experimental data were fit to a log-normal distribution function. Based on fits to the data, the mean geometric diameter $\left(\bar{D}_{g}\right)$ and geometric standard deviation $\left(\sigma_{g}\right)$ in the experiments were $7.52 \mu \mathrm{m}$ and 1.96 for kaolinite and $5.53 \mu \mathrm{m}$ and 1.82 for illite.

\subsection{Sample preparation}

Kaolinte and illite samples were purchased from Fluka (product ID: 03584) and the Clay Mineral Society (product ID: IMt-1), respectively. The mineral samples were deposited on hydrophobic glass slides using the following technique: dry dust particles were placed in a glass vessel immersed in an ultrasonic bath. A flow of ultrahigh-purity $\mathrm{N}_{2}$ was passed through the vessel, and vibrations from the ultrasonic bath caused the dust particles to be suspended in the flow of $\mathrm{N}_{2}$. This flow was directed at the hydrophobic glass slides, and the dust particles were deposited on the slides by impaction.

\subsection{Total surface area, particle size, and particle number}

The total surface area available for nucleation in each experiment, $A_{\text {total }}$, was determined from the images recorded with the optical microscope (Chernoff and Bertram, 2010; Dymarska et al., 2006; Eastwood et al., 2008, 2009). First, the projected (i.e. 2-dimensional) surface area in a given experiment was determined with digital image analysis software (Northern Eclipse). The projected surface area was then multiplied by a factor of 4 to give $A_{\text {total }}$. A factor of 4 assumes that all particles are spherical, and the surface area available for nucleation can be approximated by the geometric surface area of the particles. Based on this analysis, the total surface area of the mineral dust deposited in any particular experiment ranged from $4 \times 10^{-6}$ to $8 \times 10^{-3} \mathrm{~cm}^{2}$. Sensitivity to the assumption of spherical particles is explored in Sect. 4.5.

The size of the particles in the experiments were also determined with images from the optical microscope. In total 383 particles were analyzed for kaolinite and 363 particles for illite to extract size information. Shown in Fig. 2 are the number distributions of particles in the kaolinite and illite experiments determined from this analysis. Based on a lognormal fit to the data, the mean geometric diameter $\left(\bar{D}_{g}\right)$ and geometric standard deviation $\left(\sigma_{g}\right)$ in the experiments were $7.52 \mu \mathrm{m}$ and 1.96 for kaolinite and $5.53 \mu \mathrm{m}$ and 1.82 for illite. The optical resolution limit of the microscope was approximately $1 \mu \mathrm{m}$. Scanning electron microscopy was also carried out on some slides to ensure that the number of particles less than $1 \mu \mathrm{m}$ on the slides was small. From the electron microscope images we concluded that $<0.5 \%$ of the total surface area lies in the sub-micrometer range. Also note that from the images recorded during the freezing experiments we can conclude that ice nucleation always occurred on particles $>1 \mu \mathrm{m}$ in diameter, further confirming that particles with diameters $<1 \mu \mathrm{m}$ are not important in our experiments. The size distribution presented in Fig. 2 is different from the size distribution reported by Welti et al. (2009) for kaolinite samples also purchased from Fluka since our method of depositing particles on slides favours particles with diameters $>1 \mu \mathrm{m}$.

The number of particles in each experiment was calculated by the following equation:

$N_{\text {total }}=\frac{A_{\text {total }}}{A_{\text {average }}}$,

where $N_{\text {total }}$ is the number of particles, $A_{\text {total }}$ is the total surface area of particles calculated as described above, and $A_{\text {average }}$ is the average surface area of the particles. The value of $A_{\text {average }}$ was calculated using the following equation (Reist, 1993):

$A_{\text {average }}=\pi{\overline{D_{g}}}^{2} \exp \left(2 \ln ^{2} \sigma_{g}\right)$,

where $\bar{D}_{g}$ and $\sigma_{g}$ are the geometric mean diameter and geometric standard deviation of the number distributions discussed above and calculated from the data shown in Fig. 2. 
In each experiment the number of particles on a slide ranged from 1 to $\sim 1000$.

\section{Results}

\section{1 $S_{\text {ice, onset }}$ as a function of surface area}

The individual onset results obtained for kaolinite and illite particles are shown in Figs. 3a and 5a, respectively. Each data point represents the onset conditions observed for a single sample of dust particles, and the error bars are based on the manufacturer's stated uncertainties for the frost point hygrometer, RTD, and temperature readout. A few of the results for kaolinite particles are at $S_{\text {ice, onset values }}<1$ including error bars. This suggests that the uncertainties in $S_{\text {ice, onset }}$ are slightly larger than reported. There should not be an offset in our measurements since the relative humidity was calibrated with the ice frost point within the cell as mentioned above.

A total of 84 and 52 individual nucleation experiments were performed for kaolinite and illite, respectively. Measurements made with surface areas greater than $\sim 10^{-4} \mathrm{~cm}^{2}$ show both kaolinite and illite to be very good ice nuclei; nucleation occurred at supersaturations of less than $5 \%$. These results are consistent with previous measurements for both kaolinite and illite particles (Bailey and Hallett, 2002; Chernoff and Bertram, 2010; Eastwood et al., 2008; Kanji et al., 2008; Möhler et al., 2008a,b; Salam et al., 2006; Welti et al., 2009; Zimmermann et al., 2007, 2008). The measurements made at low surface coverages $\left(<10^{-4} \mathrm{~cm}^{2}\right)$, however, show a different trend than was observed for high surface coverages. Onset values were observed over a broad range of saturation ratios (100\% to $125 \%)$. The spread in onset values between different experiments is greater than the uncertainty in the measurements of $S_{\text {ice }}$.

\section{2 $S_{\text {ice, } r=0.05}$ as a function of surface area}

$S_{\text {ice, onset }}$ values reported in Figs. $3 \mathrm{a}$ and $5 \mathrm{a}$ correspond to the conditions when the number of nucleation events is greater than or equal to 1 . Since the time between images is $20 \mathrm{~s}$, at $S_{\text {ice, onset }}$ the rate of nucleation, $r$, is $\geq 0.05 \mathrm{~s}^{-1}$. In the previous image (collected before $S_{\text {ice, onset, }}$, which we define as $S_{\text {ice, previous }}$ ) there was no nucleation, i.e. $r=0 \mathrm{~s}^{-1}$. As a result, $r=0.05 \mathrm{~s}^{-1}$ somewhere within the range $S_{\text {ice, onset }}$

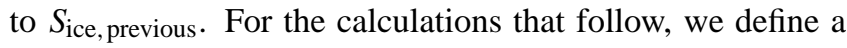
new variable, the ice saturation ratio at which the nucleation rate equals $0.05 \mathrm{~s}^{-1}\left(S_{\text {ice, } r=0.05}\right) . S_{\text {ice, } r=0.05}$ can be calculated with the following equation:

$S_{\text {ice, } r=0.05}=\frac{\left(S_{\text {ice, } \text { previous }}+S_{\text {ice, onset }}\right)}{2}$.

Figures $3 \mathrm{~b}$ and $5 \mathrm{~b}$ show individual $S_{\mathrm{ice},} r=0.05$ values as a function of surface area. The uncertainty in $S_{\text {ice, } r=0.05}$ includes the difference between $S_{\text {ice, onset }}$ and $S_{\text {ice, previous }}$ as well as the uncertainty in measuring $S_{\text {ice, onset }} S_{\text {ice, onset }}$ and
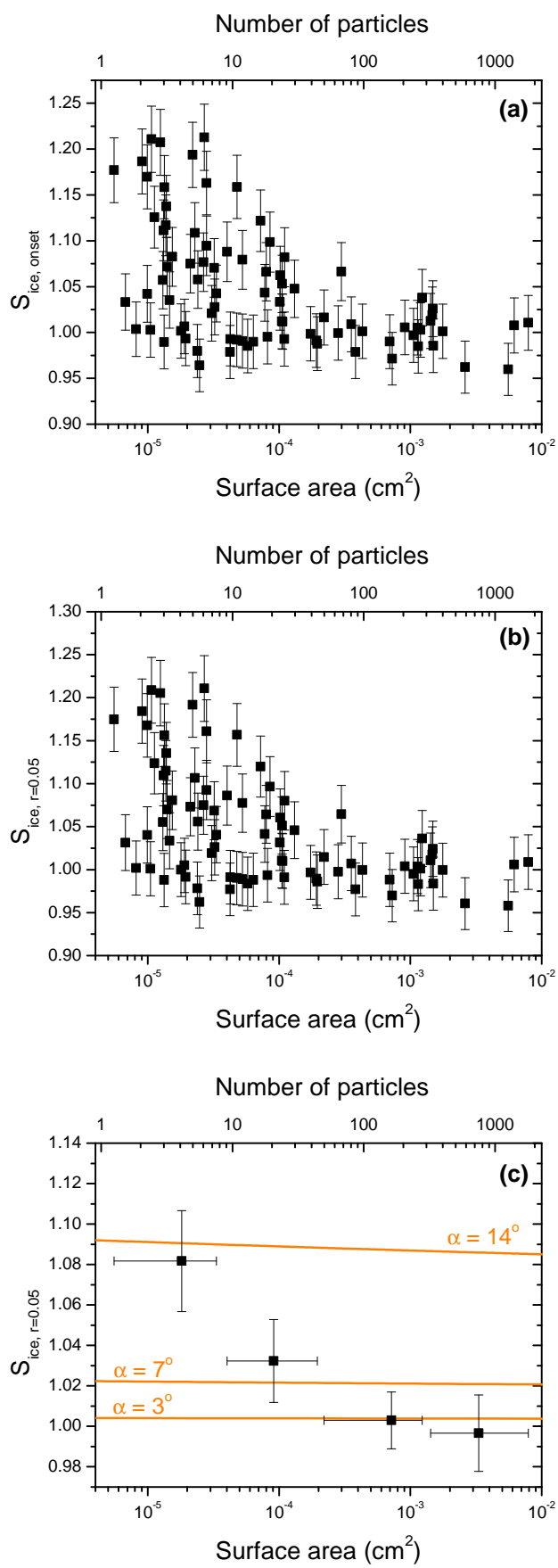

Fig. 3. Results for kaolinite particles: (a) individual onset measurements, (b) individual $S_{\text {ice, } r=0.05}$ results and (c) average $S_{\text {ice, r }=0.05}$. The average values are calculated for four equally sized bins and the horizontal error bars show the range of data points in each bin. The surface area values in (c) represent the average surface area of the points in each bin. Error in $S_{\text {ice, onset }}$ is given as experimental error in measurements of saturation. Error in $S_{\text {ice, } r=0.05}$ is based on the difference between $S_{\text {ice, onset }}$ and $S_{\text {ice, previous }}$ as well as the uncertainty in measuring $S_{\text {ice, onset }}$. Error in the average $S_{\text {ice, r }=0.05}$ represents the $95 \%$ confidence interval. Predictions are shown using the single- $\alpha$ model (orange lines) calculated using Eq. (9). In addition to surface area, the corresponding number of particles calculated from $A_{\text {average }}$ is also shown. 

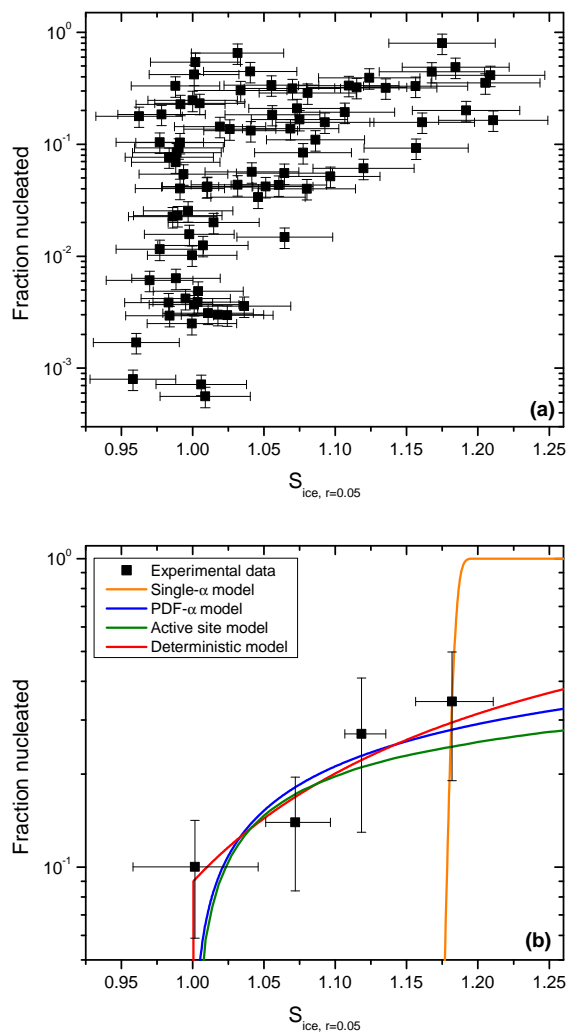

Fig. 4. Fraction of particles nucleated as a function of $S_{\text {ice, } r=0.05}$ for kaolinite. Panel (a) shows nucleated fraction for the individual experimental results. The y-error was calculated from the uncertainty in the value of $\bar{D}_{g}$. The x-error represents the uncertainty in $S_{\text {ice, r }=0.05}$. Panel (b) shows the average nucleated fraction calculated for four size bins. The range of the data points in each bin is given as the horizontal error and data points represent the average of the $S_{\text {ice, r }=0.05}$ values within each bin. The y-error bar in panel (b) represents the $95 \%$ confidence interval of the average nucleated fraction. Fits are shown for the single- $\alpha, \operatorname{PDF}-\alpha$, active site, and deterministic models.

$S_{\text {ice, } r=0.05}$ are very similar, but $S_{\text {ice, } r=0.05}$ is more useful when discussing nucleation rates.

Figures $3 \mathrm{c}$ and $5 \mathrm{c}$ show average $S_{\text {ice, } r=0.05}$ values calculated from the data presented in Figs. $3 \mathrm{~b}$ and $5 \mathrm{~b}$. To determine averages, the data were binned as a function of surface area into equally spaced bins on a logarithmic scale. The uncertainty in the average $S_{\text {ice, } r=0.05}$ values reported in Figs. $3 \mathrm{c}$ and $5 \mathrm{c}$ correspond to the $95 \%$ confidence interval for the averages. As can be seen from the figures, the average $S_{\text {ice, } r=0.05}$ values clearly increase with decreasing surface area. Kanji and Abbatt (2010) observed a similar trend for deposition nucleation.
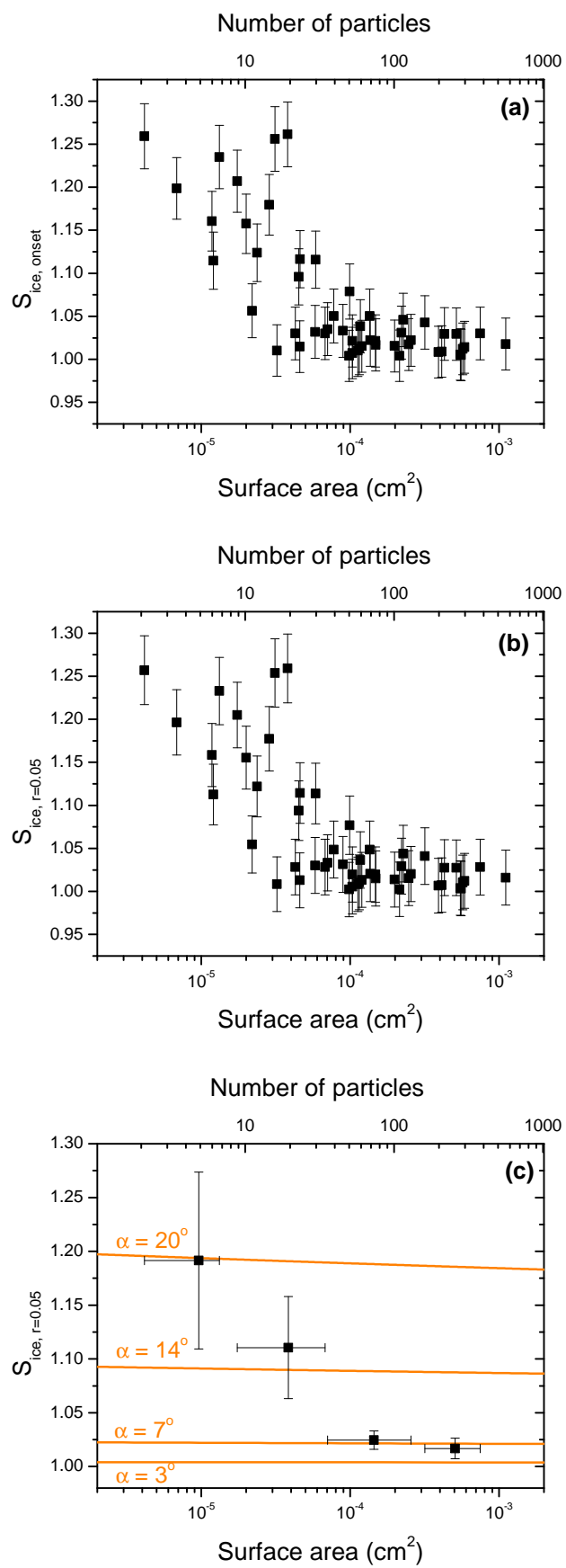

Fig. 5. Results for illite particles: (a) individual onset measurements, (b) individual $S_{\text {ice, } r=0.05}$ results and (c) average $S_{\text {ice, } r=0.05}$. The average values are calculated for four equally sized bins and the horizontal error bars show the range of data points in each bin. The surface area values in (c) represent the average surface area of the points in each bin. Error in $S_{\text {ice, onset }}$ is given as experimental error in measurements of saturation. Error in $S_{\text {ice, } r=0.05}$ is based on the difference between $S_{\text {ice, onset }}$ and $S_{\text {ice, previous }}$ as well as the uncertainty in measuring $S_{\text {ice, onset }}$. Error in the average $S_{\text {ice, } r=0.05}$ represents the $95 \%$ confidence interval. Predictions are shown using the single- $\alpha$ model (orange lines) calculated using Eq. (9). In addition to surface area, the corresponding number of particles calculated from $A_{\text {average }}$ is also shown. 


\subsection{Fraction of particles nucleated as a function of $S_{\text {ice, } r=0.05}$}

A convenient way of displaying the data involves calculating the fraction of particles nucleated in an experiment as a function of $S_{\text {ice }}$. Presenting the data in this manner allows for a direct comparison with the PDF- $\alpha$ model, the active site model, and the deterministic model (see below). Since the number of particles nucleated at $S_{\text {ice, } r=0.05}$ equals 1 , the fraction nucleated is calculated by dividing 1 by the total number of particles available to nucleate ice $\left(N_{\text {total }}\right)$.

In Figs. 4a and 6a we show the fraction of particles nucleated as a function of $S_{\text {ice, } r=0.05}$ for each of the individual experimental results. Shown in Figs. $4 \mathrm{~b}$ and $6 \mathrm{~b}$ are average fraction nucleated values calculated from the data shown in Figs. 4a and 6a. To determine averages, the data was binned as a function of $S_{\text {ice, } r=0.05}$ into 4 equally spaced bins. Figures $4 \mathrm{~b}$ and $6 \mathrm{~b}$ show an increase in fraction nucleated with increasing $S_{\text {ice, } r=0.05}$ as expected.

\section{Discussion}

\subsection{Single- $\alpha$ model}

Classical nucleation theory (Pruppacher and Klett, 1997) relates the rate of heterogeneous ice nucleation $\left(J_{\text {het }}\right.$, in units of $\mathrm{cm}^{-2} \mathrm{~s}^{-1}$ ) to the energy barrier for ice embryo formation on the substrate surface:

$J_{\text {het }}=J_{0} \exp \left(-\frac{\Delta F_{\mathrm{act}}^{*}}{k T}\right)$,

where $\Delta F_{\text {act }}^{*}$ is the activation barrier to ice nucleation, $J_{0}$ is the pre-exponential factor in $\mathrm{cm}^{-2} \mathrm{~s}^{-1}, k$ is the Boltzmann constant, and $T$ is the temperature in degrees Kelvin.

The value of the activation barrier is given by

$$
\Delta F_{\mathrm{act}}^{*}=\frac{16 \pi \sigma_{i / v}^{3} f_{\mathrm{het}}\left(m_{i / v}\right)}{3\left[N_{i} k T \ln S_{\mathrm{ice}}\right]^{2}},
$$

where $\sigma_{i / v}$ is the ice-vapour interfacial energy in $\mathrm{Jcm}^{-2}, N_{i}$ is the molecular concentration of ice in $\mathrm{cm}^{-3}, S_{\text {ice }}$ is the saturation ratio over the particles and $f_{\text {het }}\left(m_{i / v}\right)$ is the contact parameter of the embryo on the surface. For particle radii significantly larger than the radius of an ice germ (a good approximation under our conditions), $f_{\text {het }}\left(m_{i / v}\right)$ can be described by the following equation:

$f_{\text {het }}\left(m_{i / v}\right)=\frac{\left(2+m_{i / v}\right)\left(1-m_{i / v}\right)^{2}}{4}$,

where $m_{i / v}$ is the cosine of the contact angle of the ice embryo on the particle surface (i.e. $m_{i / v}=\cos \alpha$, where $\alpha$ is the contact angle). The physical meaning of the contact angle is not well understood and it is often used as a means of parametrizing laboratory data.
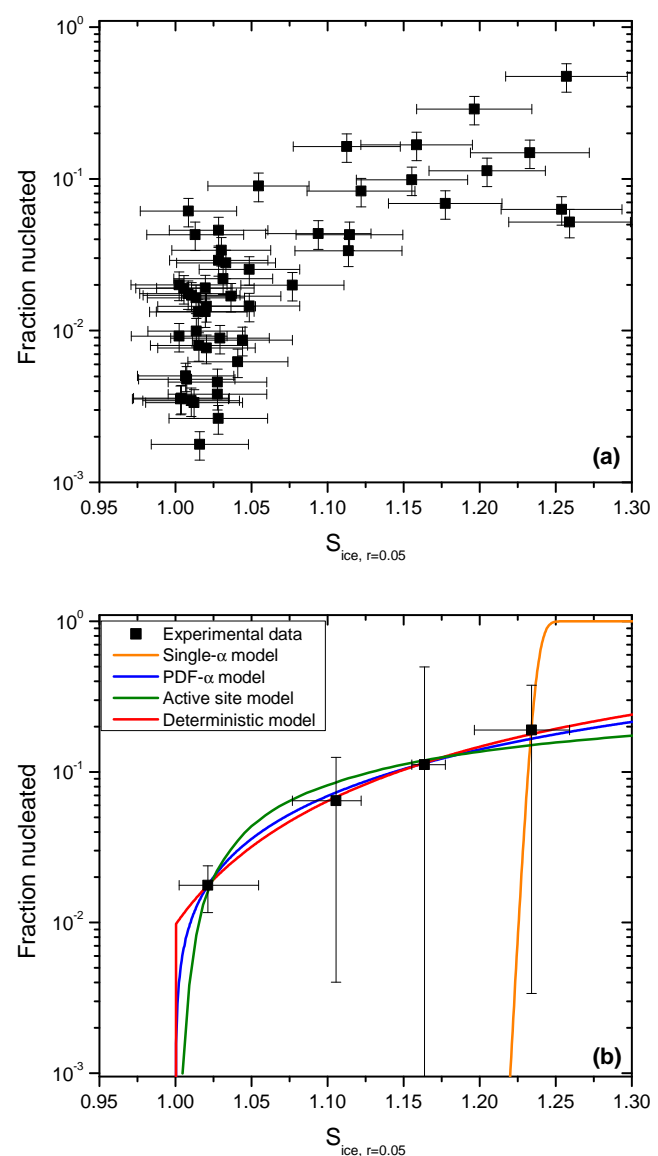

Fig. 6. Fraction of particles nucleated as a function of $S_{\text {ice, } r=0.05}$ for illite. Panel (a) shows nucleated fraction for the individual experimental results. The y-error was calculated from the uncertainty in the value of $\bar{D}_{g}$. The x-error represents the uncertainty in

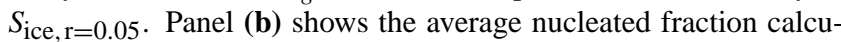
lated for four size bins. The range of the data points in each bin is given as the horizontal error and data points represent the average of the $S_{\text {ice, r }=0.05}$ values within each bin. The y-error bar in panel (b) represents the $95 \%$ confidence interval of the average nucleated fraction. Fits are shown for the single- $\alpha, \operatorname{PDF}-\alpha$, active site, and deterministic models.

Combining Eqs. (4) and (5), the overall equation for the heterogeneous nucleation rate is obtained,

$J_{\text {het }}=J_{0} \exp \left\{-\frac{16 \pi \sigma_{i / v}^{3}}{3 k T\left[k T N_{i} \ln S_{\text {ice }}\right]^{2}} f_{\text {het }}\left(m_{i / v}\right)\right\}$.

The single- $\alpha$ model is based on classical nucleation theory and assumes that every particle has the same contact angle.

The nucleation rate can be expressed as a function of area, time and number of nucleation events using the following equation:

$J_{\text {het }}=\frac{\omega}{A_{\text {total }} t}$, 
where $\omega$ is the number of nucleation events, $A_{\text {total }}$ is the total surface area of particles in $\mathrm{cm}^{2}$ and $t$ is the time scale of the measurements. Equations (7) and (8) can be combined to give the following relationship between $A_{\text {total }}, S_{\text {ice }}, T$, time and the number of nucleation events :

$$
A_{\text {total }}=\frac{\omega}{t} \frac{1}{J_{0} \exp \left\{-\frac{16 \pi \sigma_{i / v}^{3}}{3 k T\left[k T N_{i} \ln S_{\text {ice }}\right]^{2}} f_{\text {het }}\left(m_{i / v}\right)\right\}} .
$$

Equation (9) can be used to predict the relationship between surface area and $S_{\text {ice, } r=0.05}$. At $S_{\text {ice, } r=0.05}$ the number of nucleation events, $\omega$, is, by definition, 1 , and the time for nucleation is $20 \mathrm{~s}$.

In Figs. $3 c$ and $5 c$ (solid lines) we have calculated $A_{\text {total }}$ as a function of $S_{\text {ice, } r=0.05}$ and $T$ using Eq. (9), $\omega=1, t=20 \mathrm{~s}$ and different contact angles. We also used an interfacial energy of $1.065 \times 10^{-5} \mathrm{Jcm}^{-2}$ (Pruppacher and Klett, 1997), a pre-exponential factor of $10^{25} \mathrm{~cm}^{-2} \mathrm{~s}^{-1}$ (Fletcher, 1958, 1959; Pruppacher and Klett, 1997) and a molecular concentration of ice of $3.1 \times 10^{22} \mathrm{~cm}^{-3}$ (calculated from the molecular mass and density of ice (Lide, 2001)). Both the values of $\sigma_{i / v}$ and $N_{i}$ are calculated for hexagonal ice. Recent findings have shown that cubic ice is formed preferentially for homogeneous nucleation (Murray and Bertram, 2006; Murray et al., 2005) but more information is needed to determine the polymorph of ice that is formed by heterogeneous nucleation.

It can be seen in Figs. $3 \mathrm{c}$ and $5 \mathrm{c}$ that there is no single contact angle capable of accurately describing the data. Measurements made at high surface areas are described by a low value of the contact angle ( $\alpha \approx 3^{\circ}$ for kaolinite and $\alpha \approx 7^{\circ}$ for illite). Comparatively, the measurements made at the lowest surface areas are described by a much larger contact angle ( $\alpha \approx 14^{\circ}$ for kaolinite and $\alpha \approx 20^{\circ}$ for illite).

The single- $\alpha$ model can also be used to predict the fraction of particles nucleated as a function of $S_{\text {ice, } r=0.05}$ as in Figs. $4 \mathrm{~b}$ and $6 \mathrm{~b}$. Equation (10) shows the relationship between fraction of particles nucleated and the heterogeneous nucleation rate (Pruppacher and Klett, 1997):

$\frac{N_{f}}{N_{0}}=1-\int_{0}^{\infty} \exp \left[-\pi D^{2} J_{\text {het }}\left(\alpha, T, S_{\text {ice }}\right) t\right] f_{\text {num }}(D) \mathrm{d} D$,

where $\frac{N_{f}}{N_{0}}$ is the fraction of particles nucleated, $J_{\text {het }}$ is the heterogeneous nucleation rate which can be calculated from Eq. (7), $D$ is the diameter of a single kaolinite or illite particle and $f_{\text {num }}(D)$ is the number distribution calculated from data presented in Fig. 2. The value $f_{\text {num }}(D) \mathrm{d} D$ represents the fraction of particles having a diameter between $D$ and $D+$ $\mathrm{d} D$.

Shown in Figs. $4 \mathrm{~b}$ and $6 \mathrm{~b}$ (orange lines) are fits to the fraction nucleated as a function of $S_{\text {ice, } r=0.05}$ obtained by numerical integration of Eq. (10) and assuming a single contact angle. In these calculations $20 \mathrm{~s}$ was used for the time scale of the experiment as done above. It can be seen from Figs. $4 \mathrm{~b}$
Table 1. Fit parameters obtained for kaolinite. Best fits were obtained by minimizing the weighted residual sum of squares between the experimental data and the fit function. See text for further discussion on the models used.

\begin{tabular}{lccc}
\hline Model & Parameter & Value & RSS $^{\mathrm{a}}$ \\
\hline Single- $\alpha$ & $\alpha$ & $19.37^{\circ}$ & 15.771 \\
\hline PDF- $\alpha$ & $\bar{\alpha}$ & $0^{\circ}$ & 3.874 \\
& $\sigma_{\alpha}$ & $54.14^{\circ}$ & \\
\hline \multirow{2}{*}{ Active site } & $b$ & $3.8 \times 10^{9} \mathrm{~m}^{-2}$ & \multirow{2}{*}{5.424} \\
& $\beta_{1}$ & 0.01 & \\
\hline \multirow{2}{*}{ Deterministic } & $\beta_{2}$ & 0.001 & \\
& $A_{1}$ & $1.20 \times 10^{6} \mathrm{~cm}^{-2}$ & 0.541 \\
\hline
\end{tabular}

${ }^{a}$ Residual sum of squares

Table 2. Fit parameters obtained for illite. Best fits were obtained by minimizing the weighted residual sum of squares between the experimental data and the fit function. See text for further discussion on the models used.

\begin{tabular}{lccc}
\hline Model & Parameter & Value & RSS $^{\mathrm{a}}$ \\
\hline Single- $\alpha$ & $\alpha$ & $21.78^{\circ}$ & 9.7978 \\
\hline \multirow{2}{*}{ PDF- $\alpha$} & $\bar{\alpha}$ & $35.43^{\circ}$ & 0.03751 \\
& $\sigma_{\alpha}$ & $14.64^{\circ}$ & \\
\hline \multirow{3}{*}{ Active site } & $b$ & $7.6 \times 10^{9} \mathrm{~m}^{-2}$ & \\
& $\beta_{1}$ & 0.1367 & 0.6708 \\
& $\beta_{2}$ & $1.0 \times 10^{-4}$ & \\
\hline \multirow{2}{*}{ Deterministic } & $A_{1}$ & $1.46 \times 10^{6} \mathrm{~cm}^{-2}$ & \multirow{2}{*}{0.007832} \\
& $A_{2}$ & -0.9415 & \\
\hline
\end{tabular}

${ }^{a}$ Residual sum of squares

and $6 \mathrm{~b}$ that the single- $\alpha$ model cannot describe our experimental data. The parameters from the fitting procedure are listed in Tables 1 and 2.

\subsection{PDF- $\alpha$ model}

As mentioned above, the PDF- $\alpha$ model is a modification of the single- $\alpha$ model (Lüönd et al., 2010; Marcolli et al., 2007). This model assumes that a single contact angle can describe ice nucleation on an individual particle, but that a distribution of contact angles exists for an ensemble of particles. Assuming a normal distribution of contact angles, the fraction of nucleated particles is given by

$\frac{N_{f}}{N_{0}}=1-\int_{0}^{\infty} \int_{0}^{\pi} \exp \left[-\pi D^{2} J_{\text {het }}\left(\alpha, T, S_{\text {ice }}\right) t\right] f_{\alpha}(\alpha) f_{\text {num }}(D) \mathrm{d} \alpha \mathrm{d} D$,

where $f_{\alpha}(\alpha)$ is the normal probability distribution at a particular value of $\alpha$. The value $f_{\alpha}(\alpha) \mathrm{d} \alpha$ is the fraction of particles 


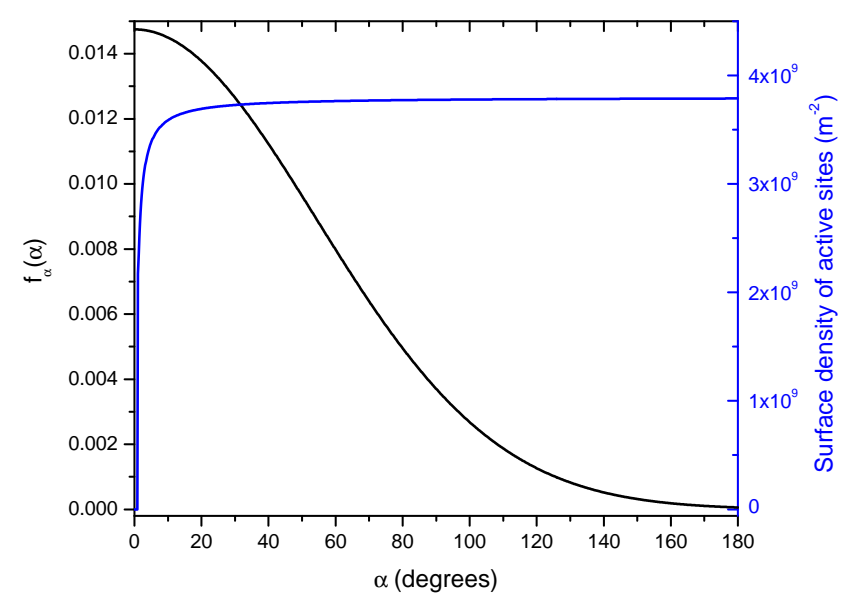

Fig. 7. Probability distribution function for the PDF- $\alpha$ model and surface density of active sites, $\rho(\alpha)$, for the active site model. Shown are the results for kaolinite particles.

having a contact angle between $\alpha$ and $\alpha+\mathrm{d} \alpha$. The normal probability distribution is described by the following equation:

$f_{\alpha}(\alpha)=\frac{1}{\sigma_{\alpha} \sqrt{2 \pi}} \exp \left[-\frac{(\alpha-\bar{\alpha})^{2}}{2 \sigma_{\alpha}^{2}}\right]$,

where $\bar{\alpha}$ and $\sigma_{\alpha}$ are the mean and standard deviation of the distribution, respectively. The value of $\bar{\alpha}$ is constrained such that $\bar{\alpha} \geq 0$ and $f_{\alpha}(\alpha)$ is normalized such that $\int_{0}^{\pi} f_{\alpha}(\alpha) \mathrm{d} \alpha=$ 1.

The blue lines in Figs. $4 \mathrm{~b}$ and $6 \mathrm{~b}$ show calculations of fraction nucleated as a function of $S_{\text {ice, } r=0.05}$ using Eq. (11). Similar to the previous calculations, an experimental time of $20 \mathrm{~s}$ was used. The data was fit by numerical integration of Eq. (11) and by varying the parameters $\bar{\alpha}$ and $\sigma_{\alpha}$.

The best fit to the kaolinite data (blue line in Fig. 4b) gave a mean contact angle $(\bar{\alpha})$ of $0^{\circ}$ and a width $\left(\sigma_{a}\right)$ of $54.1^{\circ}$. The best fit to the illite data (blue line in Fig. $6 \mathrm{~b}$ ) gave a mean contact angle of $35.4^{\circ}$ and a standard deviation of $14.6^{\circ}$. The distribution of contact angles are shown (black lines) in Fig. 7 for kaolinite and Fig. 8 for illite. Figures $4 \mathrm{~b}$ and $6 \mathrm{~b}$ show that the PDF- $\alpha$ model agrees with the experimental data within the uncertainty of the measurements.

\subsection{Active site model}

The third method used to fit the experimental data was the active site model, which is a modification of the single- $\alpha$ model that includes the existence of active sites (Fletcher, 1969; Gorbunov and Kakutkina, 1982; Han et al., 2002; Lüönd et al., 2010; Marcolli et al., 2007; Niedermeier et al., 2011). The equations presented here are the same as those presented by Lüönd et al. (2010).

In contrast to the previous models, the active site model assumes ice nucleation occurs more readily on small sites on

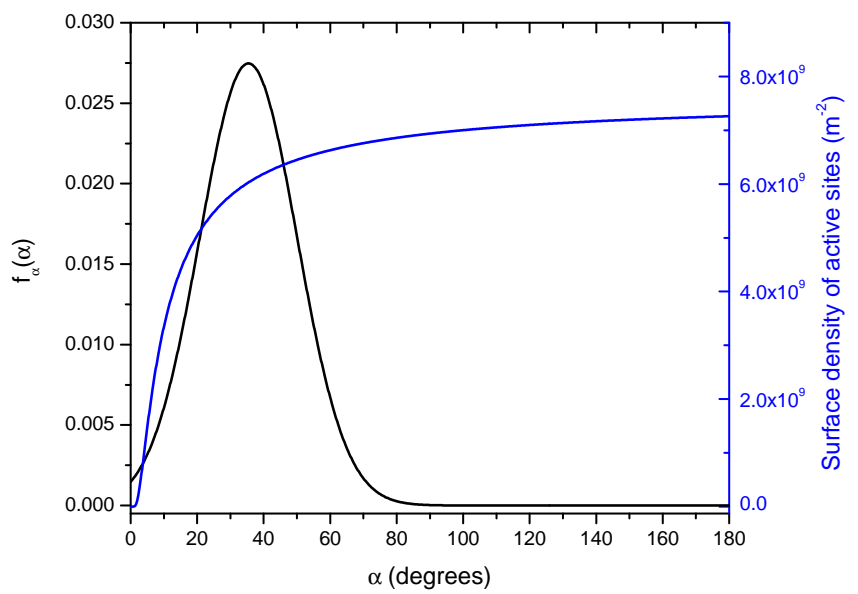

Fig. 8. Probability distribution function for the PDF- $\alpha$ model and surface density of active sites, $\rho(\alpha)$, for the active site model. Shown are the results for illite particles.

the particle surface as opposed being equally probable anywhere on the particle surface. For consistency, we assume that the size of an active site is constant and equal to $6 \mathrm{~nm}^{2}$ as done by Lüönd et al. (2010). This is calculated from the critical ice embryo size determined for homogeneous nucleation of liquid water at $239 \mathrm{~K}$ using classical nucleation theory. The active site model assumes that the probability of ice nucleation on an active site is defined by a contact angle, $\alpha_{i}$, and this contact angle can vary from site to site.

Similar to Eq. (10) presented above, the probability of nucleation on a single active site with contact angle, $\alpha$, is

$p(\alpha)=1-\exp \left[-A_{\alpha} J_{\text {het }}\left(\alpha, T, S_{\text {ice }}\right) t\right]$,

where $p(\alpha)$ is the probability of nucleation, $J_{\text {het }}\left(\alpha, T, S_{\text {ice }}\right)$ is the temperature, saturation and contact angle dependent heterogeneous nucleation rate given by Eq. (7), $A_{\alpha}$ is the area of the active site $\left(6 \mathrm{~nm}^{2}\right)$ and $t$ is the time of observation. Similarly, the probability that nucleation does not occur on a single active site with contact angle $\alpha$ is

$\bar{p}(\alpha)=\exp \left[-A_{\alpha} J_{\text {het }}\left(\alpha, T, S_{\text {ice }}\right) t\right]$.

The probability of nucleation of a single particle is described by the following equation, which takes into account the assumptions that a single particle can have multiple active sites and active sites can have a range of contact angles:

$p\left(S_{\text {ice }}\right)=1-\prod_{i=1}^{m} \bar{p}\left(\alpha_{i}\right)=1-\prod_{i=1}^{m} \exp \left[-A_{\alpha_{i}} J_{\text {het }}\left(\alpha_{i}, T, S_{\text {ice }}\right) t\right]$,

where $p\left(S_{\text {ice }}\right)$ is the probability of nucleation of a single particle and $\bar{p}\left(\alpha_{i}\right)$ is the probability that an active site with a contact angle of $\alpha_{i}$ does not nucleate ice. $A_{\alpha_{i}}$ is the total surface area of active sites with a contact angle in the range $\left(\alpha_{i}, \alpha_{i}+\Delta \alpha\right)$ where $\Delta \alpha$ is the width of the individual bin such that the total number of bins is equal to $m$. $A_{\alpha_{i}}$ represents the summation of all active sites within the specified 
range, each with an area of $6 \mathrm{~nm}^{2}$. Therefore, $A_{\alpha_{i}}$ is an integer multiple of the single active site area $\left(A_{\alpha_{i}}=n_{i}\left(6 \mathrm{~nm}^{2}\right)\right)$.

The average number of active sites on a single particle in the range $\left(\alpha_{i}, \alpha_{i}+\Delta \alpha\right), \bar{n}_{i}$, is given by

$\bar{n}_{i}=\pi D^{2} \rho\left(\alpha_{i}\right) \Delta \alpha$,

where $D$ is the diameter of the particle and $\rho(\alpha)$ is the contact angle dependent surface density of active sites (i.e. number of active sites per unit surface area per unit contact angle interval). The number of active sites on a single particle, $n_{i}$, in the range $\left(\alpha_{i}, \alpha_{i}+\Delta \alpha\right)$, was assigned using Poisson distributed random variables with the expectation value given by Eq. (16). The $n_{i}$ values determined from Poisson statistics were then used in Eq. (15) to determine the nucleation probabilities, $p\left(S_{\text {ice }}\right)$, of a single particle. This whole process was then repeated 1000 times to determine nucleation probabilities of an ensemble of 1000 particles. The diameter of each particle was assigned using uniform random numbers in the range $[0,1]$ and the cumulative distribution functions calculated from the data presented in Fig. 2. The nucleated fraction was then determined using the following equation:

$\frac{N_{f}}{N_{0}}=\frac{1}{1000} \sum_{j=1}^{j=1000} p_{j}\left(S_{\text {ice }}\right)$.

As was done by Marcolli et al. (2007) and Lüönd et al. (2010), the surface density of active sites was described using a three parameter exponential function of the following form:

$\rho(\alpha)=b \exp \left(\frac{-\beta_{1}}{\alpha-\beta_{2}}\right)$.

The experimentally determined nucleated fractions were fit to the active site model by varying the parameters, $b, \beta_{1}$, and $\beta_{2}$. Results are shown (green lines) in Figs. $4 \mathrm{~b}$ and $6 \mathrm{~b}$ for kaolinite and illite, respectively. As can be seen in the figures, the active site model fits the data within the experimental error. Fit parameters are reported in Tables 1 and 2 for kaolinite and illite, respectively. Other combinations of two of the fitting parameters, $\beta_{1}$ and $\beta_{2}$, were found which provided equivalent fits to the ones presented (i.e. no single set of parameters best described the data). This was attributed to the low number of data points upon which the fits are based.

The fact that the experimental data is in agreement with the active site model is consistent with recent computer simulations of ice nucleation at the molecular level. These simulations show that the good ice nucleation characteristics of mineral dust is not likely due to the crystallographic match between mineral surface and hexagonal ice, but rather may be due to ice nucleation on defects such as trenches (Croteau et al., 2008, 2010; Hu and Michaelides, 2007).

\subsection{Deterministic model}

A final model used here is the deterministic model (Connolly et al., 2009; Lüönd et al., 2010). For deposition nucleation, we assume that the particles have a surface density of active sites, $n_{\mathrm{s}}$, that is a function of $S_{\text {ice, } r=0.05}$, but independent of temperature over the narrow range of temperatures investigated $(239-242 \mathrm{~K})$. The assumption of temperature independence for $n_{\mathrm{S}}$ should be reasonable based on previous measurements of $S_{\text {ice, onset }}$ as a function of temperature for kaolinite particles (Eastwood et al., 2008), which show that $S_{\text {ice, onset }}$ is relatively insensitive to temperature over the range of $236-246 \mathrm{~K}$. It is also assumed that the fraction of particles nucleated at a given $S_{\text {ice }}$ is independent of time but related to $n_{\mathrm{s}}\left(S_{\text {ice }}\right)$ through the following equation:

$\frac{N_{f}}{N_{0}}=1-\int_{0}^{\infty} \exp \left[-\pi D^{2} n_{\mathrm{s}}\left(S_{\text {ice }}\right)\right] f_{\text {num }}(D) \mathrm{d} D$.

The surface density of active sites, $n_{\mathrm{s}}\left(S_{\text {ice }}\right)$, was described by Connolly et al. (2009) and Lüönd et al. (2010),

$n_{\mathrm{s}}\left(S_{\text {ice }}\right)= \begin{cases}0, & S_{\text {ice }} \leq-A_{2} \text { or } S_{\text {ice }} \leq 1 \\ A_{1}\left(S_{\text {ice }}+A_{2}\right)^{2}, & \text { otherwise }\end{cases}$

Using Eqs. (19) and (20), the experimentally determined nucleated fractions were fit using the parameters $A_{1}$ and $A_{2}$. Good agreement was found between the experimental data and the deterministic model (red lines in Figs. $4 \mathrm{~b}$ and 6b). Fit parameters can be found in Tables 1 and 2 for kaolinite and illite, respectively.

\subsection{Sensitivity of the results to the assumption of spherical particles}

The calculations above were carried out with the assumption that the surface area of a particle equals the geometric surface area (i.e. the particles are spherical). We assume this is a lower limit to the total surface area available for nucleation. Based on scanning electron microscope measurements of a limited number of mineral particles, we estimate that an upper limit to the surface area of the particles equals the geometric surface area multiplied by a factor of 50 (Eastwood et al., 2008). We have reanalyzed the experimental data and redone the calculations with the assumption that the surface area of the particles equals the geometric surface area multiplied by 50 . The results from this analysis and calculations are shown in the supplemental information (Tables S1 and S2 and Figs. S1 - S4).

In short, when using a geometric surface area multiplied by 50 , the single- $\alpha$ model does not describe the data but the PDF- $\alpha$ model, active site model, and deterministic model all fit the data within the experimental error. The fit parameters for the single- $\alpha$ and PDF- $\alpha$ models vary by less than $3 \%$ compared with the parameters presented in Tables 1 and 2 . For the deterministic model, the parameter $A_{2}$ is the same as presented in Tables 1 and 2 and the parameter $A_{1}$ is reduced by a factor of 50 . 


\subsection{Comparisons with previous measurements}

Previous studies have also used various nucleation data to test whether or not the single- $\alpha$ model can be used to accurately describe heterogeneous ice nucleation data for mineral dust particles. Several studies have shown that modifications to the single- $\alpha$ model are required for accurate predictions of heterogeneous nucleation data (Archuleta et al., 2005; Hung et al., 2003; Lüönd et al., 2010; Marcolli et al., 2007; Welti et al., 2009). Most similar to our studies, Welti et al. (2009) studied ice nucleation on mineral dust particles, including illite and kaolinite, in the deposition mode. Relative humidities with respect to ice required to activate $1 \%$ of the dust particles as ice nuclei (IN) were reported as a function of temperature. An explicit size dependence of the ice formation efficiency was observed for all dust types. $800 \mathrm{~nm}$ particles required the lowest $S_{\text {ice }}$ to activate. Similar to the main conclusions in our studies, these authors found that a single contact angle could not decribe freezing results for different particle diameters of a single mineral.

Murray et al. (2011) investigated immersion freezing by kaolinite particles as a function of dust concentration and cooling rate. In contrast with the references mentioned above, the data from this study were consistent with classical nucleation theory and the assumption of a single contact angle (the single- $\alpha$ model). The source of the kaolinite material used by Murray et al. was the Clay Mineral Society, which is a different source compared to our experiments. In addition, the work of Murray et al. investigated immersion freezing while our work examined deposition nucleation. Future studies investigating the ice nucleation properties of different mineral sources may provide some insight into the apparent discrepancies.

\section{Conclusions and atmospheric implications}

Deposition nucleation of ice on kaolinite and illite particles, two abundant minerals in the atmosphere, was investigated. The onset $S_{\text {ice }}$ conditions for ice nucleation were a strong function of the surface area available for ice nucleation. For example, in the kaolinite experiments, onset $S_{\text {ice }}$ values ranged from $100 \%$ to $125 \%$ depending on the surface area used in the experiments.

The surface area dependent results were used to test the applicability of classical nucleation theory with a single contact angle as a method to parametrize heterogeneous ice nucleation data. The surface area dependent data could not be described accurately using this model. These results add to the growing body of evidence that suggests that, in many cases, the single- $\alpha$ model is not appropriate for predictions of heterogeneous nucleation. The results also suggest that caution should be applied when using contact angles determined from the single- $\alpha$ model and onset data. This is because different contact angles can be derived from onset $S_{\text {ice }}$ data and the single- $\alpha$ model depending on the surface area used in the experiments. As an example, the contact angle consistent with our kaolinite data varied from $3^{\circ}$ to $14^{\circ}$ depending on the surface area. Fits were also performed using the PDF- $\alpha$ model, the active site model and the deterministic model. In contrast to the single- $\alpha$ model, the other models used all fit the data within experimental uncertainties. Parameters from the fits to the data are presented. These parameters are applicable to the temperature range studied ( 239 - $242 \mathrm{~K})$. Further studies are needed to determine if the parameters apply to temperatures outside this range.

\section{Supplement related to this article is available online at: http://www.atmos-chem-phys.net/12/1189/2012/ acp-12-1189-2012-supplement.pdf.}

Acknowledgements. This research was supported by the National Sciences and Engineering Research Council of Canada (NSERC). We also thank Ben Murray for helpful comments on the manuscript.

Edited by: D. J. Cziczo

\section{References}

Ansmann, A., Tesche, M., Althausen, D., Müller, D., Seifert, P., Freudenthaler, V., Hesse, B., Wiegner, M., Pisani, G., Knippertz, P., and Dubovik, O.: Influence of Saharan dust on cloud glaciation in southern Morocco during the Saharan mineral dust experiment, J. Geophys. Res., 113, D04210, doi:10.1029/2007JD008785, 2008.

Archuleta, C. M., DeMott, P. J., and Kreidenweis, S. M.: Ice nucleation by surrogates for atmospheric mineral dust and mineral dust/sulfate particles at cirrus temperatures, Atmos. Chem. Phys., 5, 2617-2634, doi:10.5194/acp-5-2617-2005, 2005.

Bailey, M. and Hallett, J.: Nucleation effects on the habit of vapour grown ice crystals from -18 to $-42^{\circ} \mathrm{C}$, Q. J. Roy. Meteorol. Soc., 128, 1461-1483, 2002.

Baker, M. B. and Peter, T.: Small-scale cloud processes and climate, Nature, 451, 299-300, doi:10.1038/nature06594, 2008.

Barahona, D., Rodriguez, J., and Nenes, A.: Sensitivity of the global distribution of cirrus ice crystal concentration to heterogeneous freezing, J. Geophys. Res., 115, D23213, doi:10.1029/2010JD014273, 2010.

Cantrell, W. and Heymsfield, A.: Production of ice in tropospheric clouds - A review, B. Am. Meteorol. Soc., 86, 795-807, doi:10.1175/BAMS-86-6-795, 2005.

Chen, J. P., Hazra, A., and Levin, Z.: Parameterizing ice nucleation rates using contact angle and activation energy derived from laboratory data, Atmos. Chem. Phys., 8, 7431-7449, doi:10.5194/acp-8-7431-2008, 2008.

Chernoff, D. I. and Bertram, A. K.: Effects of sulfate coatings on the ice nucleation properties of a biological ice nucleus and several types of minerals, J. Geophys. Res., 115, D20205, doi:10.1029/2010JD014254, 2010.

Claquin, T., Schulz, M., and Balkanski, Y. J.: Modeling the mineralogy of atmospheric dust sources, J. Geophys. Res., 104, 22243 22256, 1999. 
Connolly, P. J., Mohler, O., Field, P. R., Saathoff, H., Burgess, R., Choularton, T., and Gallagher, M.: Studies of heterogeneous freezing by three different desert dust samples, Atmos. Chem. Phys., 9, 2805-2824, doi:10.5194/acp-9-2805-2009, 2009.

Croteau, T., Bertram, A. K., and Patey, G. N.: Adsorption and structure of water on kaolinite surfaces: possible insight into ice nucleation from grand canonical monte carlo calculations, J. Phys. Chem. A, 112, 10708-10712, doi:10.1021/jp805615q, 2008.

Croteau, T., Bertram, A. K., and Patey, G. N.: Observations of high-density ferroelectric ordered water in kaolinite trenches using monte carlo simulations, J. Phys. Chem. A, 114, 8396-8405, doi:10.1021/jp104643p, 2010.

Cziczo, D. J., DeMott, P. J., Brooks, S. D., Prenni, A. J., Thomson, D. S., Baumgardner, D., Wilson, J. C., Kreidenweis, S. M., and Murphy, D. M.: Observations of organic species and atmospheric ice formation, Geophys. Res. Lett., 31, L12116, doi:10.1029/2004GL019822, 2004.

DeMott, P. J.: Laboratory Studies of Cirrus Cloud Processes, in: Cirrus, edited by: Lynch, D. K., Sassen, K., Starr, D. O., and Stephens, G., 102-136, Oxford University Press, New York, USA, 2002.

DeMott, P. J., Cziczo, D. J., Prenni, A. J., Murphy, D. M., Kreidenweis, S. M., Thomson, D. S., Borys, R., and Rogers, D. C.: Measurements of the concentration and composition of nuclei for cirrus formation, P. Natl. Acad. Sci. USA, 100, 14655-14660, doi:10.1073/pnas.2532677100, 2003.

Dymarska, M., Murray, B. J., Sun, L. M., Eastwood, M. L., Knopf, D. A., and Bertram, A. K.: Deposition ice nucleation on soot at temperatures relevant for the lower troposphere, J. Geophys. Res., 111, D04204, doi:10.1029/2005JD006627, 2006.

Eastwood, M. L., Cremel, S., Gehrke, C., Girard, E., and Bertram, A. K.: Ice nucleation on mineral dust particles: Onset conditions, nucleation rates and contact angles, J. Geophys. Res., 113, D22203, doi:10.1029/2008JD010639, 2008.

Eastwood, M. L., Cremel, S., Wheeler, M., Murray, B. J., Girard, E., and Bertram, A. K.: Effects of sulfuric acid and ammonium sulfate coatings on the ice nucleation properties of kaolinite particles, Geophys. Res. Lett., 36, L02811, doi:10.1029/2008GL035997, 2009.

Fletcher, N. H.: Size Effect in Heterogeneous Nucleation, J. Chem. Phys., 29, 572-576, 1958.

Fletcher, N. H.: Entropy Effect in Ice Crystal Nucleation, J. Chem. Phys., 30, 1476-1482, 1959.

Fletcher, N. H.: Active Sites and Ice Crystal Nucleation, J. Atmos. Sci., 26, 1266-1271, 1969.

Fornea, A. P., Brooks, S. D., Dooley, J. B., and Saha, A.: Heterogeneous freezing of ice on atmospheric aerosols containing ash, soot, and soil, J. Geophys. Res., 114, D13201, doi:10.1029/2009JD011958, 2009.

Gorbunov, B. Z. and Kakutkina, N. A.: Ice Crystal Formation on Aerosol Particles with a Non-Uniform Surface, J. Aerosol Sci., 13, 21-28, 1982.

Han, J. H., Hung, H. M., and Martin, S. T.: Size effect of hematite and corundum inclusions on the efflorescence relative humidities of aqueous ammonium nitrate particles, J. Geophys. Res., 107, D104086, doi:10.1029/2001JD001054, 2002.

Hegg, D. A. and Baker, M. B.: Nucleation in the atmosphere, Rep. Prog. Phys., 72, 056801, doi:10.1088/0034-4885/72/5/056801, 2009.
Heintzenberg, J., Okada, K., and Ström, J.: On the composition of non-volatile material in upper tropospheric aerosols and cirrus crystals, Atmos. Res., 41, 81-88, 1996.

Hoose, C., Lohmann, U., Erdin, R., and Tegen, I.: The global influence of dust mineralogical composition on heterogeneous ice nucleation in mixed-phase clouds, Environ. Res. Lett., 3, 025003 , doi:10.1088/1748-9326/3/2/025003, 2008.

Hoose, C., Kristjánsson, J. E., and Burrows, S. M.: How important is biological ice nucleation in clouds on a global scale?, Environ. Res. Lett., 5, 024009, doi:10.1088/1748-9326/5/2/024009, 2010a.

Hoose, C., Kristjánsson, J. E., Chen, J.-P., and Hazra, A.: A classical-theory-based parameterization of heterogeneous ice nucleation by mineral dust, soot, and biological particles in a global climate model, J. Atmos. Sci., 67, 2483-2503, doi:10.1175/2010JAS3425.1, 2010b.

Houghton, J. T., Ding, Y., Griggs, D. J., Noguer, M., van der Linden, P. J., Dai, X., Maskell, K., and Johnson, C. A. E.: IPCC, 2001: Climate Change 2001: The Scientific Basis. Contribution of Working Group I to the Third Assessment Report of the Intergovernmental Panel on Climate Change, Cambridge University Press, Cambridge, UK, and New York, USA, 2001.

$\mathrm{Hu}, \mathrm{X}$. L. and Michaelides, A.: Ice formation on kaolinite: Lattice match or amphoterism?, Surf. Sci., 601, 5378-5381, doi:10.1016/j.susc.2007.09.012, 2007.

Hung, H. M., Malinowski, A., and Martin, S. T.: Kinetics of heterogeneous ice nucleation on the surfaces of mineral dust cores inserted into aqueous ammonium sulfate particles, J. Phys. Chem. A, 107, 1296-1306, doi:10.1021/jp021593y, 2003.

Jensen, E. J. and Toon, O. B.: The potential impact of soot particles from aircraft exhaust on cirrus clouds, Geophys. Res. Lett., 24, 249-252, 1997.

Jensen, E. J., Toon, O. B., Pueschel, R. F., Goodman, J., Sachse, G. W., Anderson, B. E., Chan, K. R., Baumgardner, D., and Miake-Lye, R. C.: Ice crystal nucleation and growth in contrails forming at low ambient temperatures, Geophys. Res. Lett., 25, 1371-1374, 1998.

Kanji, Z. A. and Abbatt, J. P. D.: Ice nucleation onto Arizona test dust at cirrus temperatures: effect of temperature and aerosol size on onset relative humidity, J. Phys. Chem. A, 114, 935-941, doi:10.1021/jp908661m, 2010.

Kanji, Z. A., Florea, O., and Abbatt, J. P. D.: Ice formation via deposition nucleation on mineral dust and organics: dependence of onset relative humidity on total particulate surface area, Environ. Res. Lett., 3, 025004, doi:10.1088/1748-9326/3/2/025004, 2008.

Kärcher, B.: Aircraft-generated aerosols and visible contrails, Geophys. Res. Lett., 23, 1933-1936, 1996.

Kärcher, B.: Physicochemistry of aircraft-generated liquid aerosols, soot, and ice particles - 1. Model description, J. Geophys. Res., 103, 17111-17128, 1998.

Kärcher, B., Busen, R., Petzold, A., Schröder, F. P., Schumann, U., and Jensen, E. J.: Physicochemistry of aircraft-generated liquid aerosols, soot, and ice particles - 2. Comparison with observations and sensitivity studies, J. Geophys. Res., 103, 1712917147, 1998.

Khvorostyanov, V. I. and Curry, J. A.: A new theory of heterogeneous ice nucleation for application in cloud and climate models, Geophys. Res. Lett., 27, 4081-4084, 2000.

Khvorostyanov, V. I. and Curry, J. A.: The theory of ice nucleation 
by heterogeneous freezing of deliquescent mixed CCN. Part I: Critical radius, energy, and nucleation rate, J. Atmos. Sci., 61, 2676-2691, 2004.

Khvorostyanov, V. I. and Curry, J. A.: The theory of ice nucleation by heterogeneous freezing of deliquescent mixed CCN. Part II: Parcel model simulation, J. Atmos. Sci., 62, 261-285, 2005.

Khvorostyanov, V. I. and Curry, J. A.: Critical humidities of homogeneous and heterogeneous ice nucleation: Inferences from extended classical nucleation theory, J. Geophys. Res., 114, D04207, doi:10.1029/2008JD011197, 2009.

Klein, H., Nickovic, S., Haunold, W., Bundke, U., Nillius, B., Ebert, M., Weinbruch, S., Schuetz, L., Levin, Z., Barrie, L. A., and Bingemer, H.: Saharan dust and ice nuclei over central Europe, Atmos. Chem. Phys., 10, 10211-10221, doi:10.5194/acp10-10211-2010, 2010.

Koehler, K. A., Kreidenweis, S. M., DeMott, P. J., Petters, M. D., Prenni, A. J., and Mohler, O.: Laboratory investigations of the impact of mineral dust aerosol on cold cloud formation, Atmos. Chem. Phys., 10, 11955-11968, doi:10.5194/acp-1011955-2010, 2010.

Kulkarni, G. and Dobbie, S.: Ice nucleation properties of mineral dust particles: determination of onset $\mathrm{RH}_{i}$, IN active fraction, nucleation time-lag, and the effect of active sites on contact angles, Atmos. Chem. Phys., 10, 95-105, doi:10.5194/acp-10-952010, 2010.

Li, R. and Min, Q.-L.: Impacts of mineral dust on the vertical structure of precipitation, J. Geophys. Res., 115, D09203, doi:10.1029/2009JD011925, 2010.

Lide, D. R., ed.: CRC Handbook of Chemistry and Physics, CRC Press LLC, Boca Raton, USA, 82 edn., 2001.

Lüönd, F., Stetzer, O., Welti, A., and Lohmann, U.: Experimental study on the ice nucleation ability of size-selected kaolinite particles in the immersion mode, J. Geophys. Res., 115, D14201, doi:10.1029/2009JD012959, 2010.

Marcolli, C., Gedamke, S., Peter, T., and Zobrist, B.: Efficiency of immersion mode ice nucleation on surrogates of mineral dust, Atmos. Chem. Phys., 7, 5081-5091, doi:10.5194/acp-7-50812007, 2007.

Martin, S. T., Han, J. H., and Hung, H. M.: The size effect of hematite and corundum inclusions on the efflorescence relative humidities of aqueous ammonium sulfate particles, Geophys. Res. Lett., 28, 2601-2604, 2001.

Min, Q. L., Li, R., Lin, B., Joseph, E., Wang, S., Hu, Y., Morris, V., and Chang, F.: Evidence of mineral dust altering cloud microphysics and precipitation, Atmos. Chem. Phys., 9, 3223-3231, doi:10.5194/acp-9-3223-2009, 2009.

Möhler, O., Benz, S., Saathoff, H., Schnaiter, M., Wagner, R., Schneider, J., Walter, S., Ebert, V., and Wagner, S.: The effect of organic coating on the heterogeneous ice nucleation efficiency of mineral dust aerosols, Environ. Res. Lett., 3, 025007 , doi:10.1088/1748-9326/3/2/025007, 2008a.

Möhler, O., Schneider, J., Walter, S., Heymsfield, A. J., Schmitt, D., and Ulanowski, Z. J.: How coating layers influence the deposition mode ice nucleation on mineral particles, in: 15th Int. Conf. Clouds and Precipitation, Int. Comm. on Clouds and Precip., Cancun, Mexico, 2008b.

Morrison, H., Curry, J. A., and Khvorostyanov, V. I.: A new doublemoment microphysics parameterization for application in cloud and climate models. Part I: Description, J. Atmos. Sci., 62, 1665-
$1677,2005$.

Murray, B. J. and Bertram, A. K.: Formation and stability of cubic ice in water droplets, Phys. Chem. Chem. Phys., 8, 186-192, doi:10.1039/b513480c, 2006.

Murray, B. J., Knopf, D. A., and Bertram, A. K.: The formation of cubic ice under conditions relevant to Earth's atmosphere, Nature, 434, 202-205, doi:10.1038/nature03403, 2005.

Murray, B. J., Broadley, S. L., Wilson, T. W., Atkinson, J. D., and Wills, R. H.: Heterogeneous freezing of water droplets containing kaolinite particles, Atmos. Chem. Phys., 11, 4191-4207, doi:10.5194/acp-11-4191-2011, 2011.

Niedermeier, D., Hartmann, S., Shaw, R. A., Covert, D., Mentel, T. F., Schneider, J., Poulain, L., Reitz, P., Spindler, C., Clauss, T., Kiselev, A., Hallbauer, E., Wex, H., Mildenberger, K., and Stratmann, F.: Heterogeneous freezing of droplets with immersed mineral dust particles - measurements and parameterization, Atmos. Chem. Phys., 10, 3601-3614, doi:10.5194/acp-10-36012010, 2010.

Niedermeier, D., Shaw, R. A., Hartmann, S., Wex, H., Clauss, T., Voigtländer, J., and Stratmann, F.: Heterogeneous ice nucleation: exploring the transition from stochastic to singular freezing behavior, Atmospheric Chemistry and Physics, 11, 8767-8775, doi:10.5194/acp-11-8767-2011, 2011.

Parsons, M. T., Mak, J., Lipetz, S. R., and Bertram, A. K.: Deliquescence of malonic, succinic, glutaric, and adipic acid particles, J. Geophys. Res., 109, D06212, doi:10.1029/2003JD004075, 2004.

Prenni, A. J., Petters, M. D., Kreidenweis, S. M., Heald, C. L., Martin, S. T., Artaxo, P., Garland, R. M., Wollny, A. G., and Pöschl, U.: Relative roles of biogenic emissions of Saharan dust as ice nuclei in the Amazon basin, Nat. Geosci., 2, 402-405, doi:10.1038/NGEO517, 2009.

Pruppacher, H. R. and Klett, J. D.: Microphysics of Clouds and Precipitation, Atmospheric and oceanographic sciences library, Kluwer Academic Publishers, Dordrecht, The Netherlands, 2nd edn., 1997.

Reist, P. C.: Aerosol Science and Technology, McGraw-Hill, Inc., 2nd edn., 1993.

Salam, A., Lohmann, U., Crenna, B., Lesins, G., Klages, P., Rogers, D., Irani, R., MacGillivray, A., and Coffin, M.: Ice nucleation studies of mineral dust particles with a new continuous flow diffusion chamber, Aerosol Sci. Tech., 40, 134-143, doi:10.1080/02786820500444853, 2006.

Sassen, K.: Indirect climate forcing over the western US from Asian dust storms, Geophys. Res. Lett., 29, 1465, doi:10.1029/2001GL014051, 2002.

Sassen, K., DeMott, P. J., Prospero, J. M., and Poellot, M. R.: Saharan dust storms and indirect aerosol effects on clouds: CRYSTAL-FACE results, Geophys. Res. Lett., 30, 1633, doi:10.1029/2003GL017371, 2003.

Saunders, R. W., Möhler, O., Schnaiter, M., Benz, S., Wagner, R., Saathoff, H., Connolly, P. J., Burgess, R., Murray, B. J., Gallagher, M., Wills, R., and Plane, J. M. C.: An aerosol chamber investigation of the heterogeneous ice nucleating potential of refractory nanoparticles, Atmos. Chem. Phys., 10, 1227-1247, doi:10.5194/acp-10-1227-2010, 2010.

Seifert, P., Ansmann, A., Mattis, I., Wandinger, U., Tesche, M., Engelmann, R., Müller, D., Pérez, C., and Haustein, K.: Saharan dust and heterogeneous ice formation: Eleven years of cloud observations at the central European EARLINET site, J. Geophys. 
Res., 115, D20201, doi:10.1029/2009JD013222, 2010.

Twohy, C. H. and Poellot, M. R.: Chemical characteristics of ice residual nuclei in anvil cirrus clouds: evidence for homogeneous and heterogeneous ice formation, Atmos. Chem. Phys., 5, 22892297, doi:10.5194/acp-5-2289-2005, 2005.

Vali, G.: Nucleation Terminology, J. Aerosol Sci., 16, 575-576, 1985.

Welti, A., Lüönd, F., Stetzer, O., and Lohmann, U.: Influence of particle size on the ice nucleating ability of mineral dusts, Atmos. Chem. Phys., 9, 6705-6715, doi:10.5194/acp-9-6705-2009, 2009.
Zimmermann, F., Ebert, M., Worringen, A., Schütz, L., and Weinbruch, S.: Environmental scanning electron microscopy (ESEM) as a new technique to determine the ice nucleation capability of individual atmospheric aerosol particles, Atmos. Environ., 41, 8219-8227, doi:10.1016/j.atmosenv.2007.06.023, 2007.

Zimmermann, F., Weinbruch, S., Schütz, L., Hofmann, H., Ebert, M., Kandler, K., and Worringen, A.: Ice nucleation properties of the most abundant mineral dust phases, J. Geophys. Res., 113, D23204, doi:10.1029/2008JD010655, 2008. 